\title{
bFGF inhibits the activation of caspase-3 and apoptosis of P19 embryonal carcinoma cells during neuronal differentiation
}

\author{
Yasuko Miho ${ }^{1,2}$, Yoriko Kouroku1, Eriko Fujita1, \\ Takeshi Mukasa', Koko Urase ${ }^{1}$, Tadashi Kasahara ${ }^{2}$, \\ Atushi Isoai $^{3}$, Mariko Y Momoi ${ }^{4}$ and Takashi Momoi ${ }^{*, 1}$ \\ ${ }^{1}$ Division of Development and Differentiation, National Institute of \\ Neuroscience, NCNP, 4-1-1 Ogawahigashi-machi, Kodaira, Tokyo 187-8502, \\ Japan \\ 2 Department of Biochemistry, Kyouritsu College of Pharmacy, 1-5-30 \\ Shibakouen, Minato-ku, Tokyo 105-8512, Japan \\ 3 Asahi glass Co., 1150 Hasawa-cho, Kanagawa-ku Yokohama, Kanagawa \\ 221-0863, Japan \\ 4 Department of Pediatrics, Jichi Medical School, Minamikawach, Kawachi-gun, \\ Yakushiji, Tochigi 329-0498, Japan \\ * corresponding author: T. Momoi, Division of Development and Differentiation, \\ National Institute of Neuroscience, NCNP, 4-1-1 Ogawahigashi-machi, \\ Kodaira, Tokyo 187-8502, Japan. tel: 81-42-341-2711; fax: 81-42-346-1754; \\ e-mail: momoi@ncnaxp.ncnp.go.jp
}

Received 10.12.98; revised 2.2.99; accepted 12.2.99

Edited by S. Nagata

\begin{abstract}
P19 embryonal carcinoma (EC) cells undergo apoptosis during neuronal differentiation induced by all-trans retinoic acid (RA). Caspase-3-like proteases are activated and involved in the apoptosis of P19 EC cells during neuronal differentiation. ${ }^{1}$ Recently it has been shown that growth factor signals protect against apoptosis by phosphorylation of Bad. Phosphorylated Bad, an apoptotic member of the Bcl-2 family, cannot bind to $\mathrm{Bcl}-\mathrm{x}_{\mathrm{L}}$ and results in $\mathrm{Bcl}-\mathrm{x}_{\mathrm{L}}$ homodimer formation and subsequent antiapoptotic activity. In the present study, we demonstrate that this system is used generally to protect against apoptosis during neuronal differentiation. Bcl- $x_{L}$ inhibited the activation of caspase-3like proteases. Basic fibroblast growth factor (bFGF) inhibited more than $90 \%$ of the caspase-3-like activity, inhibited processing of caspase-3 into its active form, and inhibited DNA fragmentation. bFGF activated phosphatidyl-inositol-3kinase (PI3K) and stimulated the phosphorylation of Bad. Phosphorylation was inhibited by wortmannin, an inhibitor of PI3K and its downstream target Akt. Thus, Bad is a target of the FGF receptor-mediated signals involved in the protection against activation of caspase-3.
\end{abstract}

Keywords: P19 EC cells; caspase-3; bFGF; neuronal differentiation; Bcl-2 family; apoptosis; wortmannin

Abbreviations: aFGF, acidic FGF; bFGF, basic fibroblast growth factor; DRG, dorsal root ganglion; EC, embryonal carcinoma; EGF, epidermal growth factor; FGFR, FGF receptor; HGF, hepatocyte growth factor; PBS, phosphate-buffered saline; PI3K, phosphatidylinositol-3-kinase; RA, all-trans retinoic acid; RT-PCR, reverse transcription-polymerase chain reaction; SDS, sodium dodecyl sulfate; XAIP, X-linked apoptosis-inhibition protein

\section{Introduction}

Considerable evidence suggests that caspases are involved in apoptosis of various cells. ${ }^{2}$ Caspases are activated from their inactive proforms in a sequential cascade of cleavage. ${ }^{3}$ Of members of the caspase family, caspase-3, which is the farthest downstream in this cascade, is activated by processing of procaspase-3 (p32) into its active form (p20/ 17 and p12) during apoptosis. ${ }^{4}$ Caspase- 3 has been shown to play an essential role in programmed cell death in the nervous system during development. ${ }^{5-8}$

P19 EC cells differentiate into neuronal cells after treatment with all-trans retinoic acid (RA) in the aggregate form and are a good model system to study the molecular mechanism of neuronal differentiation from pluripotent cells. ${ }^{9}$ During RA-induced neuronal differentiation of P19 EC cells, many cells die or exhibit hallmarks of apoptotic cell death including cytoplasmic contraction and DNA fragmentation. ${ }^{10,11}$ RA-induced apoptosis of P19 EC cells can be inhibited by Bcl-2. ${ }^{11}$ We isolated mouse caspase-3 and -7 from P19 EC cells cDNA library ${ }^{6}$ and subsequently showed that caspase-3-like activity is increased during RAinduced neuronal differentiation and apoptosis of P19 EC cells, and that caspase-3-like proteases are involved in apoptosis of P19 EC cells. ${ }^{1}$

Recently the relation between survival signals and the mechanism underlying the cell death has been studied. IL-3 activates Raf- 1 and stimulates the phosphorylation of Bad, a member of the Bcl-2 family, resulting in an inhibition of heterodimeric complex formation with $\mathrm{Bcl}-\mathrm{x}_{\mathrm{L}}{ }^{12}$ Insulin-like growth factor inhibits the activation of caspase-1 induced by serum deprivation. ${ }^{13}$ In the vertebrate nervous system, neurotrophic factors are essential for survival of specific sensory organ neurons. ${ }^{14}$ Lack of neurotrophic factor signals induces apoptosis in the sensory neurons, including dorsal root ganglion (DRG) neurons. We recently demonstrated a relation between the activation of caspase3-like proteases and apoptosis induced by lack of neurotrophic factors; 6 caspase-3-like activity increases when apoptosis of DRGs is induced by nerve growth factor (NGF) deprivation.

Phosphatidyl-inositol-3-kinase (PI3K), a downstream effector of various growth factor signals, ${ }^{15,16}$ is also involved in cell survival. Wortmannin, an inhibitor of $\mathrm{PI} 3 \mathrm{~K},{ }^{17}$ prevents the ability of NGF to inhibit apoptosis induced by serum withdrawal. ${ }^{18}$ Wortmannin enhances 
caspase-3-like activity and apoptosis in RA-treated P19 EC cells as well as TNF-treated $U 937$ cells and anti-Fastreated Jurkat cells. ${ }^{1,19}$ Thus survival factors negatively regulate the activation of caspase-3-like proteases.

Here we demonstrate that basic fibroblast growth factor (bFGF) specifically inhibits activation of caspase-3-like proteases, including caspase-3, during neuronal differentiation of P19 EC cells by activating a downstream target of PI3K.

\section{Results}

\section{bFGF inhibits caspase-3-like protease activation and DNA fragmentation}

Caspase-3-like activity and DNA fragmentation were increased during neuronal differentiation of P19 EC cells induced by RA $(1 \mu \mathrm{M})$ (Figure 1). Caspase-3-like activity was increased at $24 \mathrm{~h}$ after RA application, plateaued at $30 \mathrm{~h}$ and then decreased (Figure 1A). The active form of caspase-3 (p17) was detected at $30 \mathrm{~h}$ after RA treatment (Figure 1B). The DNA fragmentation appeared concomitant with the increase in caspase-3-like protease activities (Figure 1C). The caspase-3-like activity, appearance of $p 17$, and DNA fragmentation induced by RA were inhibited by bFGF (10 ng/ $\mathrm{ml}$ ) (Figure 1), but the neuronal differentiation induced by RA was not inhibited (unpublished observation). These results suggest that bFGF signaling blocks apoptosis of differentiating neurons by inhibiting the activation of caspase-3-like proteases. Similarly, inhibition of caspase-3-like activity by Ac-DEVD-CHO, a specific inhibitor, blocks DNA fragmentation. ${ }^{1}$
Caspase-3-like activity was inhibited in a dose-dependent manner by bFGF $(1-10 \mathrm{ng} / \mathrm{ml})$. More than $90 \%$ of the activity was inhibited by bFGF at $1 \mathrm{ng} / \mathrm{ml}$, and $70 \%$ of the activity was inhibited by epidermal growth factor (EGF) at $10 \mathrm{ng} / \mathrm{ml}$. Hepatocyte growth factor (HGF, $10 \mathrm{ng} / \mathrm{ml}$ ) and NGF $(10 \mathrm{ng} / \mathrm{ml})$ inhibited 30 and $35 \%$ of the caspase-3-like activity induced by RA, respectively (Figure 2A). Of the FGF family members tested, bFGF and FGF9 preferentially inhibited caspase-3-like activity in P19 EC cells treated with RA, while acidic FGF (aFGF) and FGF4 had moderate inhibitory effects, and FGF7 had a very weak inhibitory effect (Figure 2B).

\section{Involvement of FGF receptor signals in the inhibition of caspase-3-like proteases}

To date, four FGF receptor (FGFR) genes have been isolated. ${ }^{20}$ Expression of mRNA for the four FGFRs was examined by reverse transcription-polymerase chain reaction (RT-PCR) in P19 EC cells during neuronal differentiation (Figure 3A). FGFR1 and 2 showed two (597 and $330 \mathrm{bp}$ ) and three $(629,383$, and $289 \mathrm{bp})$ different size of RT-PCR fragments, respectively. DNA sequence analysis confirmed that these are alternative splice products of FGFR1 and 2. The expression of FGFR1 (597 and $330 \mathrm{bp}$ ), FGFR2 (383 and $289 \mathrm{bp}$ ), and FGFR3 (446 bp) was detected consistently at high levels during neuronal differentiation, and the expression of FGFR4 (550 bp) gradually decreased.

Because FGFRs possess receptor tyrosine kinase activity, we examined whether tyrosine kinase signals are involved in the bFGF-mediated inhibition of caspase-3-like protease activation and apoptotis induced by RA. As shown
A)

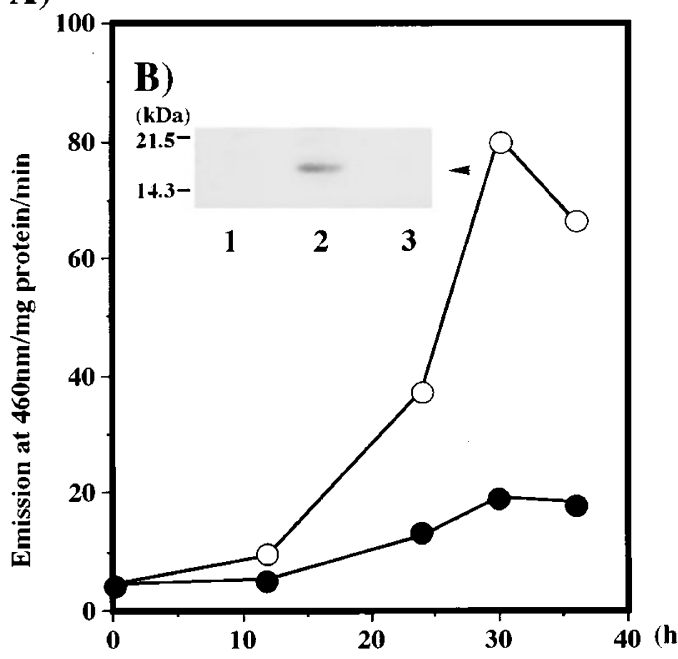

C)

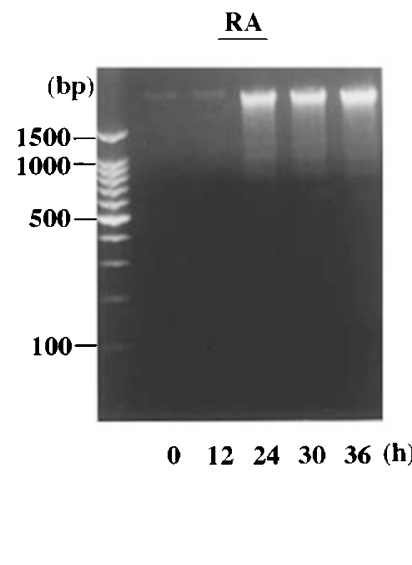

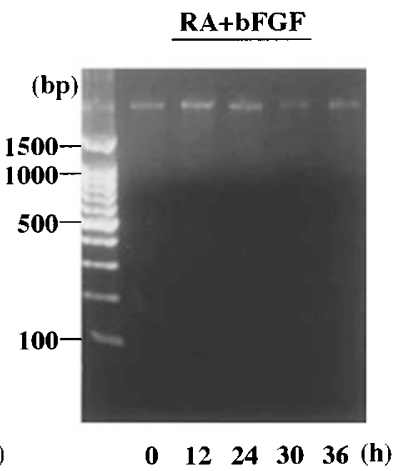

Figure 1 Effects of bFGF on the caspase-3-like activities and DNA fragmentation during the neuronal differentiation induced by RA. (A) Time-dependent activation of caspase-3-like proteases induced by RA and its inhibition by bFGF. Open and closed circles indicate the caspase-3-like activities of P19 EC cells cultured with RA alone and RA plus bFGF (10 ng/ml), respectively. (B) Processing of caspase-3 during differentiation and its inhibition by bFGF. After P19 EC cells were cultured with RA in the presence or absence of bFGF (10 ng/ml) for $30 \mathrm{~h}$, the processing of caspase-3 was examined by immunoblot analysis using anti-p20/17 antiserum. Lane 1; untreated P19 EC cells, lane 2; RA-treated cells, lane 3; RA and bFGF treated cells. An arrowhead indicates the active form of caspase-3 (p17). (C) Inhibition of RA-mediated DNA fragmentation by bFGF. DNA fragmentation was induced within $24 \mathrm{~h}$ after RA-treatment, but not induced by RA plus bFGF 
in Figure $3 B$, herbimycin $A$, a tyrosine kinase inhibitor, enhanced RA induction of caspase-3-like activity and prevented the ability of bFGF to inhibit it. These results suggest that activation of caspase-3-like proteases is negatively regulated downstream of growth factor receptor tyrosine kinase activation including FGFR kinase activation.
A)

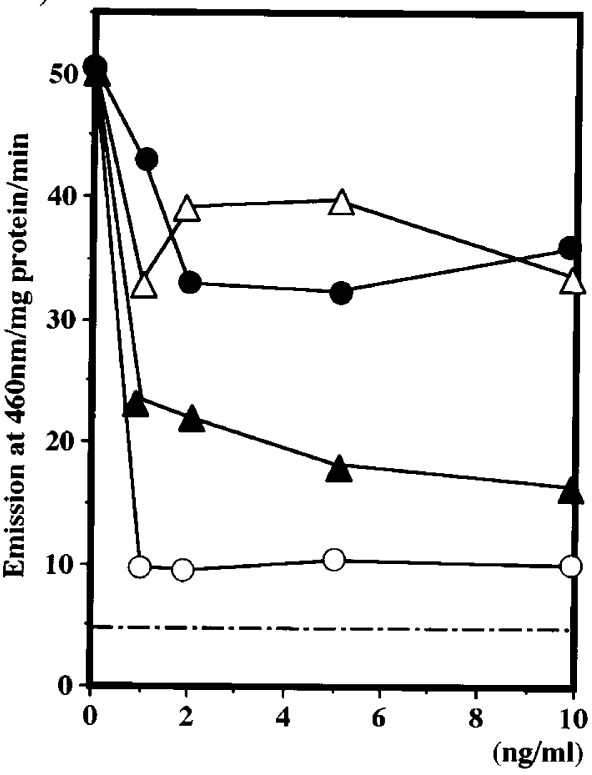

B)

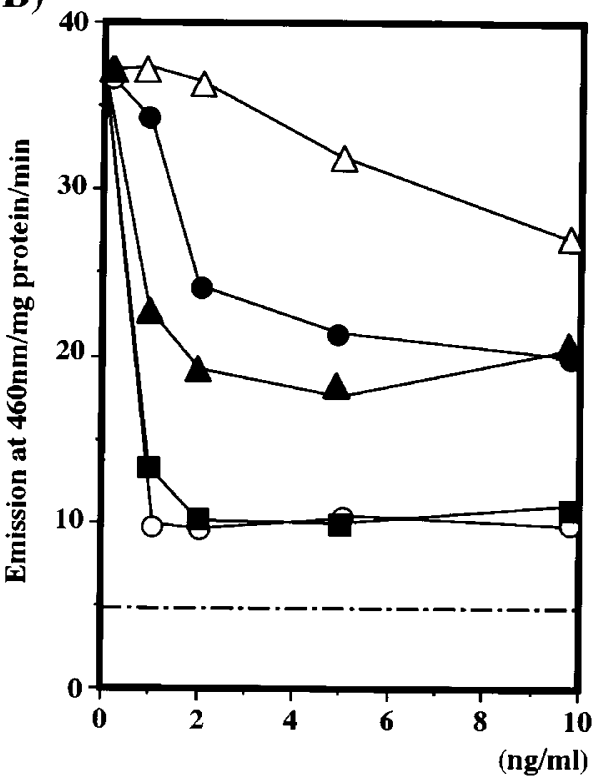

Figure 2 Inhibition of caspase-3-like proteases by various growth factors including FGF family. (A) Dose-dependent inhibition of caspase-3-like proteases by growth factors. The caspase-3-like activities induced by RA for $30 \mathrm{~h}$ were inhibited by HGF (closed circles), bFGF (open circles), EGF (closed triangles), and NGF (open triangles). (B) Dose-dependent inhibition of caspase-3-like activities by member of FGFs. The caspase-3-like protease activities induced by RA for $30 \mathrm{~h}$ was inhibited by aFGF (closed circles), bFGF (open circles), FGF4 (closed triangles), FGF7 (open triangles), and FGF9 (closed squares). Broken lines indicate caspase-3-like activities of the untreated P19 EC cells

A)

$\begin{array}{lllllll}0 & 3 & 6 & 12 & 2436 & 48 & (h)\end{array}$

FGFR1

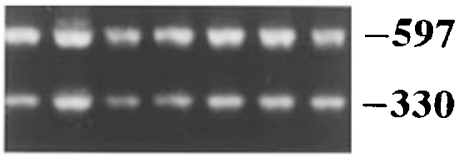

FGFR2

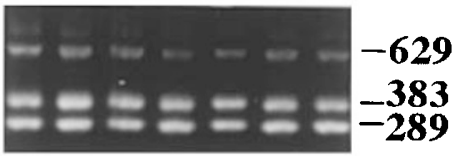

FGFR3

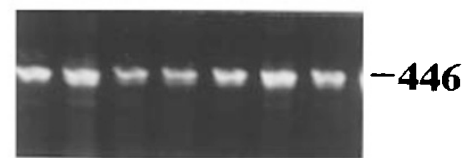

FGFR4

\section{B)}

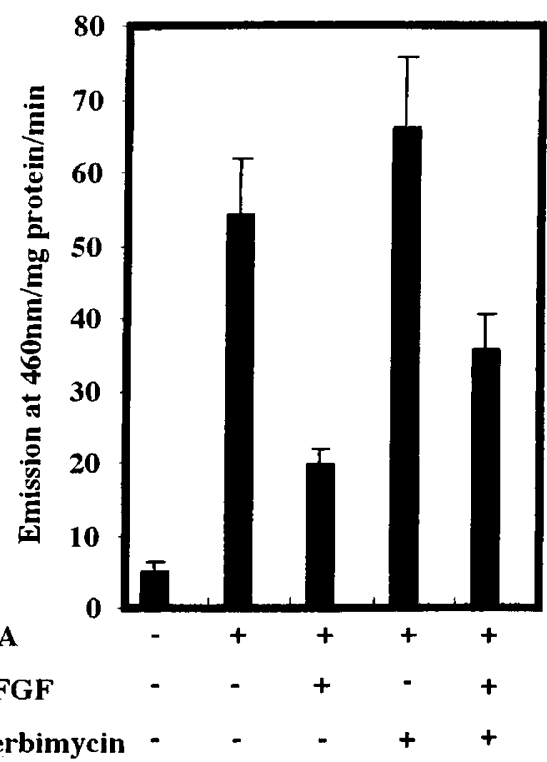

Figure 3 Involvement of FGFRs signals in the regulation of the activation of caspase-3-like proteases. (A) RT-PCR analysis of the expression of FGFR family during neuronal differentiation of P19 EC cells induced by RA. Two PCR products (597 and $330 \mathrm{bp)}$ of FGFR1 and three PCR products (629, 383 and $289 \mathrm{bp)}$ of FGFR2 were alternative splicing products of FGFR1 and FGFR2, respectively. (B) Effect of herbimycin A on the caspase-3-like activities induced by RA. P19 EC cells were incubated with RA in the presence or absence of bFGF $(10 \mathrm{ng} / \mathrm{ml})$ or herbimycin A $(100 \mathrm{nM})$ for $30 \mathrm{~h}$. Bars indicate the standard deviation 
A)

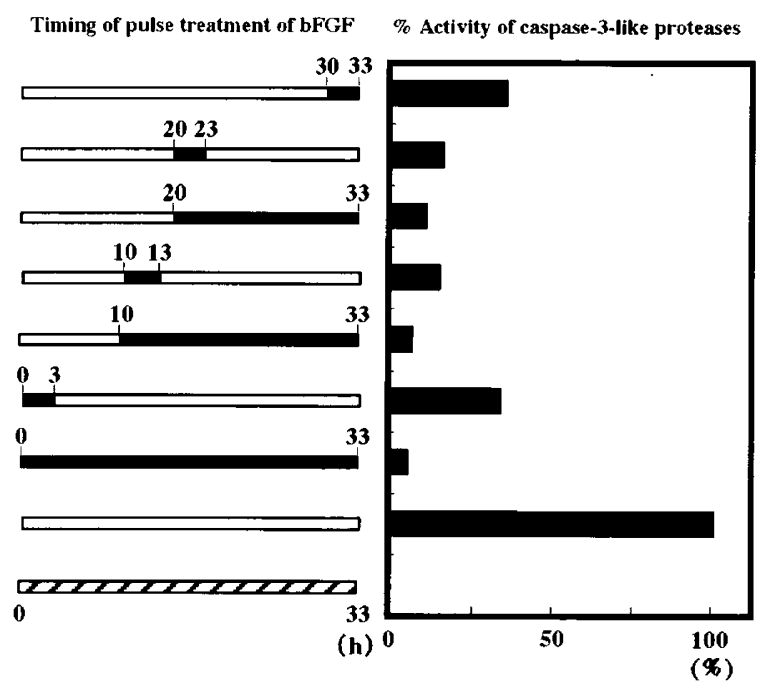

B)

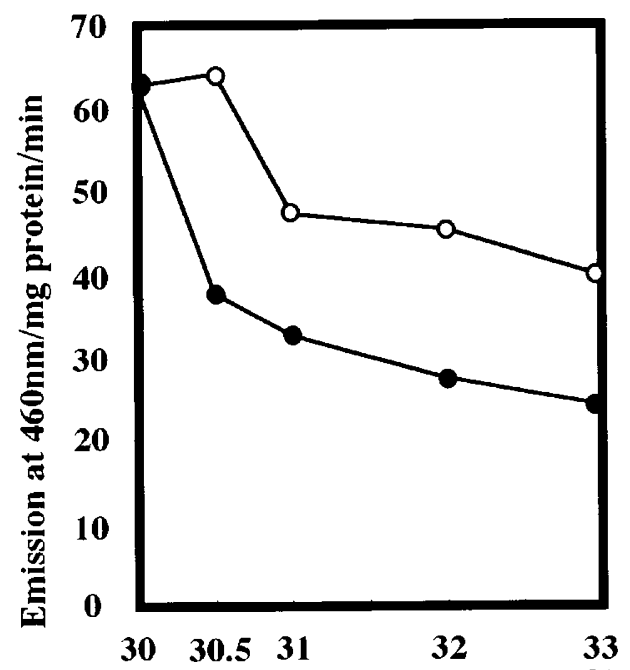

C)

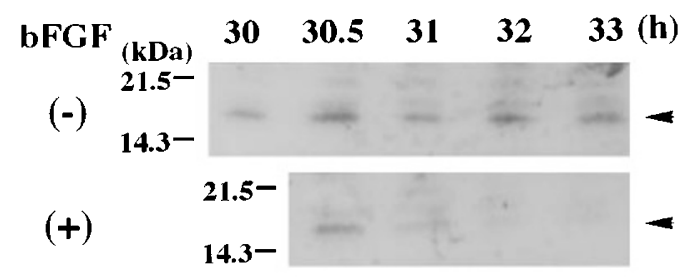

Figure 4 Effects of pulse treatment of bFGF on the caspase-3-like activities and processing of caspase-3 during neuronal differentiation of P19 EC cells. (A) Effects of pulse treatment of bFGF on the caspase-3-like activities during neuronal differentiation of P19 EC cells. Open, closed and shadow bars indicate the period of RA treatment, RA plus bFGF $(10 \mathrm{ng} / \mathrm{ml})$ treatment, and untreatment, respectively. The caspase-3-like activities of the untreated cells and RA-treated cells for $33 \mathrm{~h}$ are normalized as $0 \%$ and $100 \%$, respectively. Time course of the changes of the caspase-3-like activity (B) and the processing of caspase-3 (C) in $3 \mathrm{~h}$ after addition of bFGF. bFGF was added at $30 \mathrm{~h}$ after P19 EC cells were incubated with RA. Open and closed circles indicate the caspase-3-like activity with or without bFGF, respectively. Arrowheads indicate the active form of caspase- 3 ( $p 17$ ). Plus and minus symbols indicate the presence or absence of bFGF, respectively

\section{Effects of pulse treatment of bFGF on the activation of caspase-3}

To specify when bFGF efficiently inhibits the activation of caspase-3 during neuronal differentiation, we examined the effect of pulse treatment of bFGF. Caspase-3-like activity was inhibited by pulse treatment $(3 \mathrm{~h})$ with bFGF after RA treatment. Pulse treatment with $\mathrm{bFGF}$ at $0 \mathrm{~h}$ after RA addition inhibited $60 \%$ of caspase-3-like activity. At 10 and $20 \mathrm{~h}$ after RA treatment, bFGF pulse treatment inhibited more than $80 \%$ of this activity. Interestingly, even at $30 \mathrm{~h}$, when caspase-3-like proteases had already been activated, bFGF successfully inhibited $60 \%$ of the activity within $3 \mathrm{~h}$ (Figure 4A). bFGF inhibited the processing of caspase-3 within $1 \mathrm{~h}$, correlating with the decrease in caspase-3-like activity (Figure 4B and C). The active fragment of caspase3 (p17) rapidly disappeared after bFGF treatment. Thus, pulse treatment with bFGF as well as continuous treatment inhibited the processing of caspase-3. This indicates that inhibition of caspase-3 by bFGF is not due to the prevention of the neuronal differentiation, but due to the direct influence of the FGFR-mediated phosphorylation signals.

\section{Inhibition of caspase-3-like proteases by $\mathrm{Bcl}-\mathrm{x}_{\mathrm{L}}$}

The effect of $\mathrm{Bcl}-\mathrm{x}_{\mathrm{L}}$ on caspase-3 was examined (Figure 5). Cells overexpressing $\mathrm{Bcl}-\mathrm{x}_{\mathrm{L}}$ differentiated normally into Map2-positive neurons under the condition used (unpublished observation). Caspase-3-like protease activity during neuronal differentiation induced by RA was much lower in cells

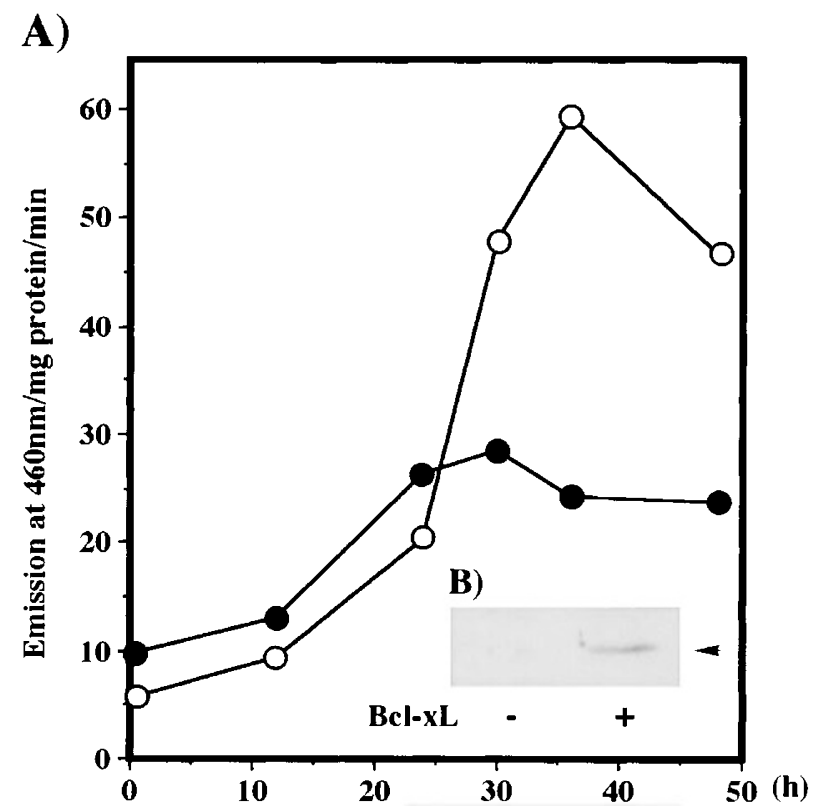

Figure 5 Effect of $\mathrm{Bcl}-\mathrm{x}_{\mathrm{L}}$ on the activation of caspase-3-like proteases during neuronal differentiation of P19 EC cells. (A) Caspase-3-like activities. Open and closed circles indicate the caspase-3-like activities of the wild-type of P19 EC cells and cells overexpressing Bcl- $x_{L}$, respectively. (B) Immunoblot analysis of $\mathrm{Bcl}-\mathrm{x}_{\mathrm{L}}$. Plus and minus of $\mathrm{Bcl}-\mathrm{x}_{\mathrm{L}}$ indicate the cells overexpressing $\mathrm{Bcl}-\mathrm{x}_{\mathrm{L}}$ and wild-type P19 EC cells, respectively 
A)

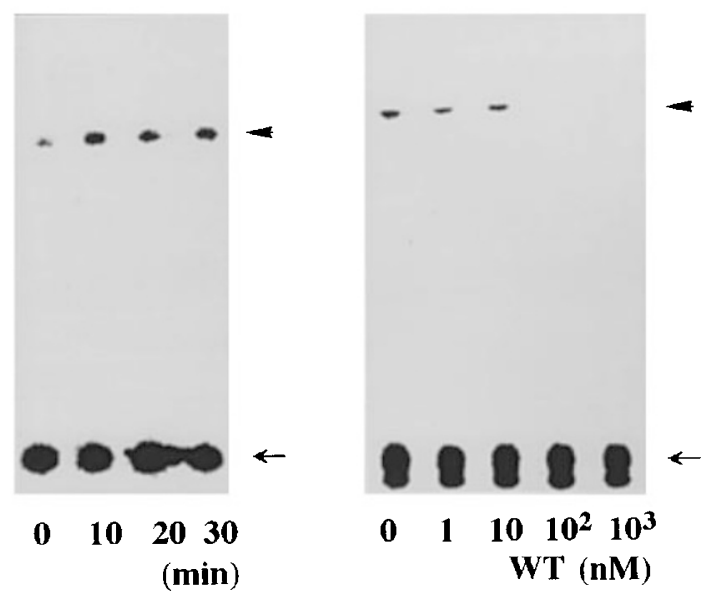

B)

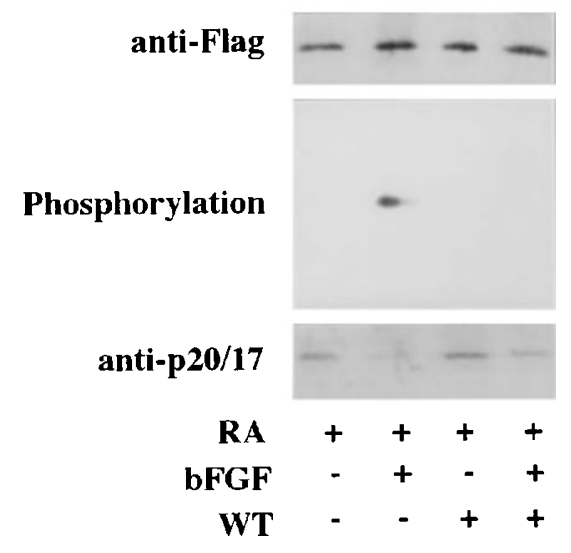

Figure 6 FGFR-mediated signals involved in the inhibition of the processing of caspase-3. (A) PI3K activity induced by bFGF and its inhibition by wortmannin Arrowheads and arrows indicate phosphatidyl-inositol-3-phosphate and the position which samples are applied, respectively. Left panel; After P19 EC cells were cultured with RA in the aggregate form for $24 \mathrm{~h}, \mathrm{bFGF}(10 \mathrm{ng} / \mathrm{ml})$ was added. PI3K activity was measured at the indicated times after addition of bFGF. Right panel; After P19 EC cells were cultured with RA $(1 \mu \mathrm{M})$ in the aggregate form for $24 \mathrm{~h}, \mathrm{bFGF}(10 \mathrm{ng} / \mathrm{ml})$ and wortmannin at the indicated concentrations were added. PI3K activity was measured at 20 min after addition of bFGF and wortmannin. WT indicates wortmannin. (B) The effect of bFGF and wortmannin on the phosphorylation of Bad and processing of caspase- 3 induced by RA. After FLAG-tagged Bad was transfected into P19 EC cells and incubated with RA for $24 \mathrm{~h}$, bFGF (10 ng/ml) and wortmannin $(100 \mathrm{nM})$ were added. Phosphorylation and processing of caspase- 3 was examined at 30 min after addition of bFGF or and wortmannin

overexpressing $\mathrm{Bcl}-\mathrm{x}_{\mathrm{L}}$ than in wild-type cells. Similar to bFGF, $\mathrm{BCl}-\mathrm{x}_{\mathrm{L}}$ inhibited caspase-3-like proteases during neuronal differentiation.

\section{Phosphorylation of Bad in response to bFGF treatment}

$\mathrm{Bcl}-\mathrm{x}_{\mathrm{L}}$ forms a heterocomplex with unphosphorylated Bad, an apoptotic member of the Bcl-2 family, but not with phosphorylated Bad. ${ }^{12}$ Recently, it has been shown that Bad is phosphorylated by Akt, a downstream target of PI3K. ${ }^{21}$ As shown in Figure 6A, bFGF time-dependently activated $\mathrm{PI} 3 \mathrm{~K}$, and this activity was sensitive to treatment with wortmannin. bFGF stimulated phosphorylation of Bad, and this phosphorylation was also inhibited by wortmannin (Figure $6 \mathrm{~B})$. In correlation with the phosphorylation of Bad, the processing of caspase-3 was decreased. Wortmannin partially prevented the ability of bFGF to inhibit the processing of caspase-3.

\section{Discussion}

\section{Molecular mechanism by which bFGF inhibits caspase- 3 activation and DNA fragmentation}

The FGF signaling pathway involves a large number of FGFs and at least four receptors. ${ }^{20}$ FGF family members can share receptors and affect a variety of biological functions including proliferation, morphogenesis, and suppression of apoptosis during development via a more complex signal transduction system. FGFs protect against apoptosis of various cells including endothelial cells, ${ }^{22}$ lens cells, ${ }^{23}$ and oligodendroglia cells $^{24}$ during development, and protect neurons against hypoxia- or oxygen-induced apoptosis. ${ }^{25,26}$ Recently, we found that FGFs are involved in the protection against apoptosis of neuroepithelial cells (unpublished observation). In the present study, we demonstrated that bFGF protected against the apoptosis during neuronal differentiation of P19 EC cells by inhibiting the activation of caspase-3-like proteases.

Since bFGF has an ability to inhibit the differentiation of neural stem cells, ${ }^{27}$ the possibility arises that bFGF inhibits caspase- 3 activation by preventing the neuronal differentiation of P19 EC cells. However, this possibility is unlikely in our case, because pulse treatment of bFGF as well as continuous treatment inhibited the caspase- 3 activation in the RA-treated P19 EC cells within 1-3h (Figure 4). Furthermore, bFGF-treated P19 EC cells or Bcl-x $\mathrm{L}_{\mathrm{L}}$-overexpressing P19 EC cells as well as untreated cells differentiate normally into Map-2-positive neurons; percentage of Map-2-positive cells did not change in response to bFGF treatment or Bcl- $\mathrm{x}_{\mathrm{L}}$ expression (unpublished observation). These results indicate that the inhibition of caspase-3 induced by bFGF and $\mathrm{Bcl}-\mathrm{x}_{\mathrm{L}}$ is not related to the inhibition of the neuronal differentiation.

\section{FGFR signals inhibiting the activation of caspase-3}

Herbimycin A blocked the bFGF-mediated inhibition of caspase-3-like activity (Figure $3 \mathrm{~B}$ ), suggesting that activation of caspase-3 is regulated by FGFR-mediated phosphorylation signals. Pulse treatment of bFGF rapidly decreased the level of the active form fragment ( $p 17$ ) as well as caspase-3-like activity (Figure 4), suggesting that FGFR-mediated phosphorylation signals inhibit the activation of upstream caspase-3 processing enzyme. Active form ( $p 17)$ may be very sensitive 
to degradation enzymes, and degrade rapidly after inhibition of the processing enzyme.

The relation between growth factor signals and apoptosis has been a topic of recent interest. Bad promotes cell death by heterodimerizing with $\mathrm{Bcl}-2$ or $\mathrm{BCl}-\mathrm{X}_{\mathrm{L}}$ cell death antagonists. ${ }^{12,28}$ Survival factors IL-3 and Raf-1 inhibit the function of Bad through phosphorylation; phosphorylated Bad fails to bind to $\mathrm{Bcl}-\mathrm{x}_{\mathrm{L}}$, promoting the formation of the $\mathrm{Bcl}-\mathrm{x}_{\mathrm{L}}$ homodimer complex, which serves an antiapoptotic function. Bcl- $\mathrm{x}_{\mathrm{L}}$ inhibits the activation of caspase-9, one of the processing enzyme of caspase-3. ${ }^{29} \mathrm{PI} \mathrm{K}$ is a signaling molecule associated with growth factor receptors that are involved in cell proliferation. ${ }^{30}$ Akt, one of the downstream targets of PI3K, is known to regulate neuronal survival. ${ }^{31}$ Like Bad phosphorylated by IL-3 or Raf-1, Bad phosphorylated by Akt promotes the formation of $\mathrm{Bcl}-\mathrm{x}_{\mathrm{L}}$ homodimer complexes and antiapoptotic activity, ${ }^{12,32}$ suggesting that the activated PI3K-Akt pathway is one way in which growth factors protect against apoptosis.

bFGF activated PI3K and stimulated phosphorylation of Bad, while wortmannin, an inhibitor of $\mathrm{PI} \mathrm{K}^{17}$ and its downstream target $\mathrm{Akt}^{33}$ inhibited the phosphorylation of Bad induced by bFGF (Figure 6). The level of Bad phosphorylation correlated with the level of the caspase3 active fragment induced by bFGF, suggesting that Bad is one of the targets of the PI3K-Akt pathway. Thus, activation of the PI3K-Akt pathway by FGFR may promote the antiapoptotic function of $\mathrm{Bcl}-\mathrm{x}_{\mathrm{L}}$ through phosphorylation of Bad. However, the possibility should not be excluded that phosphorylation of other $\mathrm{Bcl}-2$ family members or their downstream targets including caspase- 9 and downstream of caspase-3, for example, the X-linked apoptosis-inhibition protein (XAIP), ${ }^{34}$ may be involved in FGFR-mediated protection against caspase-3 activity.

\section{Materials and Methods}

\section{Cell culture}

P19 EC cells, originally established by McBurney et al. $^{9}$ were kindly donated by Dr. Hamada (Osaka University, Osaka, Japan). Neuronal differentiation of P19 EC cells was induced by following conditions originally described by McBurney et al. ${ }^{9}$ P19 EC cells were cultured in the aggregate form in the presence of $1 \mu \mathrm{M} R A$ in bacterial dishes for 2 days and then cultured in the non-aggregate form in the absence of RA for 2 days in cell culture dishes. All experiments were performed in the aggregate culture condition with $\mathrm{RA}(1 \mu \mathrm{M})$ unless otherwise noted.

\section{Isolation of fragmented DNA}

DNA isolation was performed according to Prigent et al. ${ }^{35}$ with some modification. P19 EC cells treated with RA alone or RA plus bFGF (Mallinckrodt Inc, Paris, KY, USA) were lysed with $400 \mathrm{ml}$ of lysis buffer (20 mM Tris- $\mathrm{HCl}$ pH 7.4, $20 \mathrm{mM}$ EDTA and 1\% Triton X-100). Lysis was allowed to proceed on ice for $10 \mathrm{~min}$ and the mixture was centrifuged for $10 \mathrm{~min}$ at $10000 \times \mathrm{g}$. The supernatant was digested with $50 \mu \mathrm{g} / \mathrm{ml}$ RNase A at $37^{\circ} \mathrm{C}$ for $1 \mathrm{~h}$. This was followed by a proteinase $\mathrm{K}$ digestion at $50 \mu \mathrm{g} / \mathrm{ml}$ at $37^{\circ} \mathrm{C}$ for $1 \mathrm{~h}$. After phenolchloroform extraction, the DNA was then precipitated by adding 2.5 vol of $100 \%$ ethanol and $\mathrm{CH}_{3} \mathrm{COONa}(0.3 \mathrm{M}$ final concentration). DNA ladders were visualized on $1.8 \%$ Nusieve agarose (Takara, Kyoto, Japan) gel.

\section{Caspase-3-like activity}

P19 EC cells were cultured with RA in the aggregated form for $48 \mathrm{~h}$. To examine the effect of growth factors and kinases on caspase-3-like activity, P19 EC cells were incubated with RA in the presence or absence of various growth factors including aFGF (UBI, Lake Plasid, NY, USA), bFGF, FGF4 (R\&D Systems Inc, Minneapolis, MN, USA), FGF7 and FGF9 (Pepro Tech Inc, London, England), EGF and HGF (TOYOBO, Osaka, Japan), and NGF (Wako, Osaka, Japan) or herbimycin A (Wako) at the indicated concentrations for various periods. After incubation, cells were washed twice with phosphatebuffered saline (PBS), and the cell pellets were lysed in PBS containing $0.2 \%$ Triton $\mathrm{X}-100$ on ice for $10 \mathrm{~min}$. After centrifugation at $10000 \times g$ for $5 \mathrm{~min}$, the cell extracts (50 $\mu \mathrm{g}$ protein) were incubated with $10 \mathrm{mM}$ Ac-DEVD-MCA (Peptide Institute, Osaka, Japan), a synthetic peptide of the cleavage site of poly-ADP ribose polymerase, in incubation buffer (50 mM Tris- $\mathrm{HCl} \mathrm{pH} 7.5,1 \mathrm{mM} \mathrm{DDT}$ ) at $37^{\circ} \mathrm{C}$ for $20 \mathrm{~min}$ in order to measure caspase-3-like activity. The reactions were halted by the addition of $10 \%$ sodium dodecyl sulfate (SDS). Fluorescence intensity was measured at $380 \mathrm{~nm}$ for excitation and at $460 \mathrm{~nm}$ for emission.

\section{Assay of PI3K activity}

Activity of PI3K was assayed as described by Arcaro and Wymann. ${ }^{17}$ P19 EC cells were incubated with bFGF and wortmannin at various concentrations (1-1000 nM) and lysed in lysis buffer (200 mM Tris$\mathrm{HCl} \mathrm{pH} \mathrm{7.5,1} \mathrm{mM} \mathrm{MgCl} 2,1 \mathrm{mM} \mathrm{CaCl} 2,137 \mathrm{mM} \mathrm{NaCl}, 1 \mathrm{mM} \mathrm{NaVO}$, $1 \%$ NP-40, $10 \%$ glycerol, $1 \mathrm{mM}$ PMSF, $10 \mu \mathrm{g} / \mathrm{ml}$ leupeptin). After centrifugation at $13000 \times g$ for $10 \mathrm{~min}$, the supernatant was incubated with anti-PI3K (p85) (MBL, Nagoya, Japan) at $4^{\circ} \mathrm{C}$ overnight. The immunocomplex was precipitated with a mixture of protein $A$ and $G$ (Promega, Madison, WI, USA), and suspended in $20 \mathrm{ml}$ of $20 \mu \mathrm{M}$ HEPES buffer ( $\mathrm{pH}$ 7.4). The immunocomplex was incubated with $1 \mu \mathrm{Ci}$ $\left.{ }^{32} \mathrm{P}\right] \gamma-\mathrm{ATP}$ in the reaction buffer containing phosphatidylinositol $(200 \mu \mathrm{g} / \mathrm{ml})$ and phosphatidylserine $(200 \mu \mathrm{g} / \mathrm{ml})$ at $25^{\circ} \mathrm{C}$ for indicated period and then subjected to thin layer chromatography. The thin layer plate (Merck, Darmstadt, Germany) was developed with chloroform/ methanol $/ 25 \%$ ammonia/ $\mathrm{H}_{2} \mathrm{O}(86: 76: 8.9: 15.1)$. After development, the thin layer was exposed to a Fuji image analyzer.

\section{RT-PCR assay}

The expression of FGFRs in P19 EC cells during neuronal differentiation was examined by RT-PCR using the following primers; ${ }^{20} 5^{\prime}$-TTCTGGGCTGTGCTGGTCAC-3' and $5^{\prime}$-GCGAACCTTGTAGCCTCCAA-3' for FGFR1, 5'-TTCATCTGCCTGGTCTTGGT-3' and 5'-AATAAGGCTCCAGTGCTGGTTTC-3' for FGFR2, 5'-CTAGTGTTCTGCGTGGCGGT-3' and 5'-TTCTTATCCATTCGCTCCGG-3' for FGFR3, 5'-CTGTTGAGCATCTTTCAGGG-3' and 5'-CGTGGAAGGCCTGTCCATCC-3' for FGFR4. Total RNA was prepared from P19 EC cells using the guanidium thiocyanate method. ${ }^{36}$ Total RNA $(1 \mu \mathrm{g})$ was subjected to RT-PCR as described in the manual from Perkin-Elmer, 1 cycle at $95^{\circ} \mathrm{C}$ for $2 \mathrm{~min}, 30$ cycles at $95^{\circ} \mathrm{C}$ for $1 \mathrm{~min}$ and at $60^{\circ} \mathrm{C}$ for $2 \mathrm{~min}$, and 1 cycle at $60^{\circ} \mathrm{C}$ for $7 \mathrm{~min}$. The PCR products were subjected to $3 \%$ Nusieve gel (Takara) electrophoresis. The identity of the PCR products was confirmed by DNA sequence analysis. 


\section{Immunoblot analysis of caspase-3 cleavage}

To detect the cleavage of mouse caspase-3, we prepared a cleavage site-directed antiserum against human and mouse caspase-3 (anti-p20/17). ${ }^{7,8,19}$ Cell pellets were lysed in PBS containing $0.2 \%$ Triton $\mathrm{X}-100$ on ice for $10 \mathrm{~min}$. After centrifugation at $10000 \times \mathrm{g}$ for $10 \mathrm{~min}$, the cell extracts (30 $\mu \mathrm{g}$ protein) were subjected to SDS gel (12\%) electrophoresis. Proteins were electrophoretically transferred to nitrocellulose filters. After the filters were incubated with anti-p20/17, immunoreactivity was detected by alkaline phosphatase-conjugated goat anti-rabbit immunoglobulin (Promega) and nitro blue tetrazolium and 5bromo-4-chloro-3-indolyl-1-phosphate.

\section{P19 EC cells overexpressing Bcl- $\mathbf{x}_{\mathrm{L}}$}

Rat $b c l-x_{L}$ was inserted into the $E c o R I$ site of the pMKIT-Neo expression vector. PMKIT-Neo- $b c l-x_{L}$ was transfected into P19 EC cells according to the calcium-phosphate method ${ }^{37}$ and cells expressing $\mathrm{Bcl}-\mathrm{x}_{\mathrm{L}}$ were selected by incubating them in the presence of $\mathrm{G} 418(500 \mu \mathrm{g} / \mathrm{ml})$ for 2 weeks. The expression of $\mathrm{Bcl}-\mathrm{x}_{\mathrm{L}}$ was detected by immunoblot analysis using anti-Bcl- $x_{L}$. Cells overexpressing $\mathrm{Bcl}-\mathrm{x}_{\mathrm{L}}$ were differentiated into neuronal cells by incubation in the presence of $R A$.

\section{Phosphorylation of Bad by bFGF}

Full-length mouse Bad was obtained by RT-PCR of total RNA from mouse embryos using the following primers; 5'-ACGAATTCAATGGGAACCCCAAAGCAGCCC-3' and 5'-ATGAATTCTCACTGGGAGGGGGTGGAGC-3'. ${ }^{38}$ Isolated mouse Bad was inserted into the EcoRI site of the FLAG-tagged CMV expression vector (Kodak, New Haven, CT, USA) and transfected into P19 EC cells. At $12 \mathrm{~h}$ after transfection, the transfected P19 EC cells were incubated with RA in the aggregate form for $24 \mathrm{~h}$, and then incubated further with RA in the presence or absence of bFGF and or wortmannin (Sigma, St Louis, MO, USA) in phosphate-free medium with ${ }^{32} \mathrm{P}(50 \mu \mathrm{Ci} / \mathrm{ml})$ for $30 \mathrm{~min}$ and then lysed in lysis buffer $(50 \mathrm{mM}$ Tris- $\mathrm{HCl} \mathrm{pH} 7.4,150 \mathrm{mM} \mathrm{NaCl}, 1 \%$ Triton X-100, $1 \mathrm{mM} \mathrm{Na} 3 \mathrm{VO}_{4}, 10 \mathrm{mM} \mathrm{NaF}, 1 \mu \mathrm{g} / \mathrm{ml}$ leupeptin). After centrifugation at $10000 \times g$ for $10 \mathrm{~min}$, the cell extracts $(100 \mathrm{mg}$ protein) were incubated with anti-Bad antibody (MBL) and precipitated with Sepharose-conjugated protein $A$ and $G$. The immunoprecipitation complex was subjected to SDS gel (12\%) electrophoresis. After transfer to nitrocellulose filters, immunoreactivity was detected by anti-FLAG (Kodak) and alkaline phosphatase-conjugated goat antimouse immunoglobulin (Promega). The immunoreactivity was detected by nitro blue tetrazolium and 5-bromo-4-chloro-3-indolyl1-phosphate. The filter was also exposed to a Fuji image analyzer.

\section{Acknowledgments}

We thank S. Ohta and K. Maruyama for rat $b c l-x_{L} c D N A$ and the anti$\mathrm{Bcl}-\mathrm{x}_{\mathrm{L}}$ and $\mathrm{pMKIT}-\mathrm{Neo}$ expression vector, respectively. This work was supported by Research Grants 8A-1 for Nervous and Mental Disorders from the Ministry of Health and Welfare of Japan and by Grants-in-Aid for Scientific Research on Priority Areas (Nos. 0229105 and 03263228) from the Ministry of Education, Science and Culture of Japan and by Research Grants from the Human Science Foundation.

\section{References}

1. Mukasa T, Khoroku Y, Tsukahara T, Momoi MY, Kimura I and Momoi T (1997b) Wortmannin enhances CPP32-like activity during neuronal differentiation of P19 embryonal carcinoma cells induced by retinoic acid. Biochem. Biophys. Res. Commun. 232: 192-197

2. Yuan J-Y, Shaham S, Ledoux S, Ellis HM and Horvitz HR (1993) The C. elegans cell death gene ced-3 encodes a protein similar to mammalian interleukin-1 beta converting enzyme. Cell 75: $641-652$

3. Thornberry NA and Lazebnik Y (1998) Caspases: Enemies within. Science 281: $1312-1316$

4. Nicholson DW, Ali A, Thornberry NA, Vaillancourt JP, Ding CK, Gallant M, Gareau Y, Griffin PR, Labelle M, Lazebnik YA, Munday NA, Raju SM, Smulson ME, Yamin T-T, Yu VL and Miller DK (1995) Identification and inhibition of the ICE/CED-3 protease necessary for mammalian apoptosis. Nature 376: $37-43$

5. Kuida K, Zheng TS, Na S, Kuan C, Yang D, Karasuyama H, Rakic P and Flavell RA (1996) Decreased apoptosis in the brain and premature lethality in CPP32deficient mice. Nature 384: 368-372

6. Mukasa T, Urase K, Momoi MY, Kimura I and Momoi T (1997a) Specific expression of CPP32 in sensory neurons of mouse embryos and activation of CPP32 in the apoptosis induced by a withdrawal of NGF. Biochem. Biophys. Res. Commun. 231: $770-774$

7. KourokuY, Urase K, Fujita E, Isahara K, Ohsawa Y, Uchiyama Y, Momoi MY and Momoi T (1998) Detection of activated Caspase-3 by a cleavage site-directed antiserum during naturally occurring DRG neurons apoptosis. Biochem. Biophys. Res. Commun. 247: 780-784

8. Urase K, Fujita E, Miho Y, Kouroku Y, Mukasa T, Yagi Y, Momoi MY and Momoi T (1998) Detection of activated Caspase-3 (CPP32) in the vertebrate nervous system during development by a cleavage site-directed antiserum. Brain Res. Dev. Brain Res. 111: 77-87

9. McBurney MW, Jones-Villeneuve EM, Edwards MK and Anderson PJ (1982) Control of muscle and neuronal differentiation in a cultured embryonal carcinoma cell line. Nature 299: 165-167

10. SlackRS, Skerjanc IS, Lach B, Craig J, Jardine Kand McBurney MW (1995) Cells differentiating into neuroectoderm undergo apoptosis in the absence of functional retinoblastoma family proteins. J. Cell. Biol. 129: 779-788

11. Okazawa H, Shimizu J, Kamei M, Imafuku I, Hamada H and Kanazawa I (1996) $\mathrm{Bcl}-2$ inhibits retinoic acid-induced apoptosis during the neural differentiation of embryonal stem cells. J. Cell. Biol. 132: 955-968

12. Zha J, Harada H, Yang E, Jockel J and Korsmeyer SJ (1996) Serine phosphorylation of death agonist $B A D$ in response to survival factor results in binding to 14-3-3 not BCL-X. Cell 87: 619-628

13. Jung Y-K, Miura M and Yuan J (1996) Suppression of interleukin-1- $\beta$-converting enzyme-mediated cell death by insulin-like growth factor. J. Biol. Chem. 271: $5112-5117$

14. Snider WD (1994) Functions of the neurotrophins during nervous system development: what the knockouts are teaching us. Cell 77: 627-638

15. Cantley LC, Auger KR, Carpenter C, Duckworth B, Graziani A, Kapeller R and Soltoff S (1991) Oncogenes and signal transduction. Cell 64: 281-302

16. Baxter RM, Cohen P, Obermeier A, Ullrich A, Downes CP and Doza YN (1995) Phosphotyrosine residues in the nerve-growth-factor receptor (TrkA). Their role in the activation of inositolphospholipid metabolism and protein kinase cascades in phaeochromcytoma (PC12) cells. Eur. J. Biochem. 234: 84-91

17. Arcaro A and Wymann MP (1993) Wortmannin is a potent phosphatidylinositol3kinase inhibitor: the role of phosphatidylinositol3,4,5-trisphosphate in neutrophil responses. Biochem. J. 296: 297-301

18. Yao R and Cooper GM (1995) Requirement for phosphatidylinositol-3 kinase in the prevention of apoptosis by nerve growth factor. Science 267: 2003-2006

19. Fujita E, Kouroku Y, Miho Y, Tsukahara T, Ishiura S and Momoi T (1998) Wortmannin enhances activation of CPP32 (Caspase-3) induced by TNF or antiFas. Cell Death Differ. 5: 289-297

20. Ozawa K, Uruno T, Miyakawa K, Seo M and Imamura T (1996) Expression of the fibroblast growth factor family and their receptor family genes during mouse brain development. Brain Res. Mol. Brain Res. 41: 279-288

21. del Peso L, Gonzalez-Garcia M, Page C, Herrera R and Nunez G (1997) Interleukin-3-induced phosphorylation of BAD through the protein kinase Akt. Science 278: 687-689 
22. Karsan A, Yee E, Poirier GG, Zhou P, Craig R and Harlan JM (1997) Fibroblast growth factor-2 inhibits endothelial cell apoptosis by bcl-2-dependent and independent mechanisms. Am. J. Pathol. 151: 1775-1784

23. Chow RL, Roux GD, Roghani M, Palmer MA, Rifkin DB, Moscatelli DA and Lang RA (1995) FGF suppresses apoptosis and induces differentiation of fibre cells in the mouse lens. Development 121: $4383-4393$

24. Yasuda T, Grinspan J, Stern J, Franceschini B, Bannerman P and Pleasure D (1995) Apoptotis occurs in the oligodendroglial lineage, and is prevented by basic fibroblast growth factor. J. Neurosci. Res. 40: 306-317

25. Tamatani M, Ogawa S and Tohyama M (1998) Roles of Bcl-2 and caspases in hypoxia-induced neuronal cell death: a possible neuroprotective mechanism of peptide growth factors. Brain Res. Mol. Brain Res. 58: 27-39

26. Satoh T, Enokido Y, Kubo T, Yamada M and Hatanaka H (1998) Oxygen toxicity induces apoptosis in neuronal cells. Cell. Mol. Neurobiol. 18: 649-666

27. Okabe S, Forsberg-Nilsson K, Spiro AC, Segal M and McKay RD (1996) Development of neuronal precursor cells and functional postmitoticneurons from embryonic stem cells in vitro. Mech. Dev. 59: 89-102

28. Kelekar A, Chang BS, Harlan JE, Fesik SW and Thompson CB (1997) Bad is a $\mathrm{BH} 3$ domain-containing protein that forms an inactivating dimer with $\mathrm{Bcl}-\mathrm{XL}$. Mol. Cell. Biol. 17: 7040-7046

29. Li P, Nijhawan D, Budihardjo I, Srinivasula SM, Ahmad M, Alnemri ES and Wang X (1997) Cytochrome $c$ and dATP-dependent formation of Apaf-1/caspase-9 complex initiates an apoptotic protease cascade. Cell 91: 479-489
30. Carpenter CL and Cantley LC (1990) Phosphoinositide kinases. Biochemistry 29: $11147-11156$

31. Dudek H, Datta SR, Franke TF, Birnbaum MJ, Yao R, Cooper GM, Segal RA, Kaplan DR and Greenberg ME (1997) Regulation of neuronal survival by the serine-threonine protein kinase Akt. Science 275: 661-665

32. Datta SR, Dudek H, Tao X, Masters S, Fu H, Gotoh Y and Greenberg ME (1997) Akt phosphorylation of BAD couples survival signals to the cell-intrinsic death machinery. Cell 91: 231-241

33. Franke TF, Kaplan DR, Cantley LC and TokerA (1997) Direct regulation of the Akt proto- oncogene product by phosphatidylinositol-3,4-bisphosphate. Science 275: $665-668$

34. Deveraux QL, Takahashi R, Salvesen GS and Reed JC (1997) X-linked IAP is a direct inhibitor of cell-death proteases. Nature 388: 300-304

35. Prigent $P$, Blanpied C, Aten J and Hirsch F (1993) A safe and rapid method for analyzing apoptosis-induced fragmentation of DNA extracted from tissues or cultured cells. J. Immunol. Methods 160: 139-140

36. Sambrook J, Fritsch EF and Maniatis T (1989) Molecular Cloning: A Laboratory Manual. 2nd Ed, Cold Spring Harbor Lab Press, Cold Spring Harbor, NY.

37. Graham FL and van der Eb AJ (1973) A new technique for the assay of infectivity of human adenovirus 5 DNA. Virology 52: $456-467$

38. Yang E, Zha J, Jockel J, Boise LH, Thompson CB and Korsmeyer SJ (1995) Bad, a heterodimeric partner for $\mathrm{Bcl}-\mathrm{XL}$ and $\mathrm{Bcl}-2$, displaces $\mathrm{Bax}$ and promotes cell death. Cell 80: 285-291 